\title{
INFLUENCE OF THE MALE ON LITTER SIZE IN MICE
}

\author{
G. A. FINN* \\ Department of Physiology, Royal Veterinary College, London, $\mathcal{N} . W .1$
}

(Received 10th Fuly 1963)

\begin{abstract}
Summary. The size of litters sired by male mice throughout their entire life has been followed. Each male was paired with a new young female approximately every 5 months so as to avoid any effect of ageing of the dam. There were three groups of males (1) entire, (2) unilaterally castrated and (3) 9 months younger than the first two groups. The results indicated that the individual male, regardless of treatment, had a significant influence on the size of litter sired. Unilateral castration, however, did not significantly affect litter size, nor did the age of the male.
\end{abstract}

\section{INTRODUCTION}

The size of litters produced by polytocous mammals is of considerable practical as well as academic interest, and the roles of various genetic and environmental factors in determining litter size have been fairly extensively studied (Bittner, 1936; Falconer, 1960; Kranowska, 1960; Finn, 1963). The part played by the sire has, however, received little attention, although his influence may be of practical importance, especially in so far as his performance may be affected by age.

The number of offspring produced in a litter is the result of the interaction of several variables. Firstly, the number of eggs ovulated sets the upper limit to litter size. This maximum is very often not attained because of failure of fertilization or implantation, or intra-uterine death of embryos. Although ovulation rate is presumably a purely maternal factor, the others could possibly be influenced by the male.

The aim of the present experiment was to determine whether the sire had any influence on litter.size in mice throughout his entire life. Further, it was thought that it would be of interest to see whether the removal of one testis had any effect on performance. In the female the removal of one ovary has a very significant effect on reproductive output. However, in view of the differences in gametogenesis between the sexes it is unlikely that unilateral castration in the male would have such a pronounced effect, although it might well influence the performance of the ageing male and thus provide information on the process of ageing.

\section{MATERIALS AND METHODS}

The object of the experimental design was to have each male breeding continually with a female until he died. From previous work it is known that the

* Present address: Department of Biology, Wye College, Nr. Ashford, Kent. 
females of the strain used maintain a fairly constant litter size for the first 6 to 9 months (the so-called plateau period) (Biggers, Finn \& McLaren, 1962). In the present experiment, therefore, the females were changed well before the end of this period so as to avoid any effect of ageing of the female. The reproductive life of the male can thus be divided into a number of periods, each period representing his pairing with an individual female.

The mice used were TO strain, randomly bred in the Royal Veterinary College animal house. They were housed under natural lighting conditions with the temperature maintained at approximately $70^{\circ} \mathrm{F}$ and fed $a d$ lib. on commercial mouse food. Eighteen 6-week-old male mice were divided randomly into two groups. Those in Group 1 had one testicle removed aseptically, whilst those in Group 2 were left entire. A female mouse of approximately the same age was allocated at random to each male. Cages were inspected every morning for litters which were counted, sexed and then removed. The first females were removed after approximately 6 months and replaced with young virgins. After a further 4 months the females were again changed and at the same time another seven males (Group 3) aged 6 weeks were paired with young females, allocated from the same population. Two further changes of females in all three groups were made at intervals of approximately 5 months. The females were always allocated to all the groups of males at the same time, using a table of random numbers so that any variation of litter size within females for any period would be randomly distributed throughout all the groups under test.

The experiment was concluded when all the males in Groups 1 and 2 had died. Some of the males in these groups were autopsied and the testes examined histologically. Because of the lapse of several hours between death and fixation, some of the testes were not in a fit state for histological examination and had to be discarded.

\section{RESULTS}

One of the males in Group 2 failed to breed with any of the females and has therefore been omitted from the analysis. The remaining males in Groups 1 and 2 bred continuously with the first three females allocated to them, although one died towards the end of the third period. During the fourth period a further four males died, and the remainder died during the fifth. It is apparent therefore that the data for the first three periods is balanced. The death of a single male at the end of Group 3 will have only a very slight effect on this as he could only have sired one more litter in the time available if he had lived.

The variance between litter sizes for the first three periods for Groups 1 and 2 has therefore been analysed to determine whether there is a significant difference between (a) the two groups, (b) the three periods and (c) between individual males. The interaction of males with periods has also been obtained. The analysis is shown in Table 1 . The difference between groups is not significant at the $10 \%$ level, thus indicating that at least during the active part of their reproductive life the removal of one testis has not affected the size of the litters sired.

The difference between periods is highly significant indicating that the litter size performance of the young females fluctuates in this random bred 
strain of mice. This is not an effect due to ageing of the male; the changes, although pronounced, do not show a regression with age (Table 2).

The variance due to individual males is significant at the $0.1 \%$ level. However, the interaction of male with period, or in other words, male with female, is not significant. Thus it seems that the male does influence the litter size of the dams he inseminates and that this is not due to interaction with the female, but is a characteristic of individual males.

TABLE 1

ANALYSIS OF THE VARIANCE BETWEEN LITTER SIZES FOR GROUPS 1 AND 2 DURING PERIODS 1, 2 AND 3

\begin{tabular}{|c|c|c|c|c|c|}
\hline Source of variation & d.f. & Sum of square & Mean squares & $F$ & $P$ \\
\hline $\begin{array}{l}\text { Males } \\
\text { Groups } \\
\text { Within groups } \\
\text { Periods } \\
\text { Interaction } \\
\text { (males } \times \text { period) } \\
\text { Error }\end{array}$ & $\begin{array}{rr}16 & 1 \\
& 15 \\
2 & \\
32 & \\
212 & \end{array}$ & $\begin{array}{rr}396 & 15 \\
& 381 \\
775 & \\
& \\
157 & \\
1319 & \end{array}$ & $\begin{array}{c}15 \\
25 \cdot 4 \\
387 \cdot 5 \\
\\
4 \cdot 91 \\
6 \cdot 222\end{array}$ & $\begin{array}{r}2.411 \\
4.082 \\
62.279 \\
0.789\end{array}$ & $\begin{array}{c}\text { ns } \\
0.1 \% \\
0.1 \% \\
\text { ns }\end{array}$ \\
\hline Total & 262 & 2647 & & & \\
\hline
\end{tabular}

TABle 2

MEAN LITTER SIZES SIRED (WITH S.E. OF THE MEAN)

\begin{tabular}{|c|c|c|c|c|c|c|}
\hline Group & $\begin{array}{l}\text { No. } \\
\text { males }\end{array}$ & $\begin{array}{c}\text { 1st period } \\
\text { (Feb. to } \mathcal{J} u l y)\end{array}$ & $\begin{array}{c}\text { 2nd period } \\
\text { (Aug. to Nov.) }\end{array}$ & $\begin{array}{c}\text { 3rd period } \\
\text { (Dec. to April) }\end{array}$ & $\begin{array}{c}\text { 4th period } \\
\text { (May to Sept.) }\end{array}$ & $\begin{array}{c}5 \text { th period } \\
\text { (Sept. to Feb.) }\end{array}$ \\
\hline 1 & 9 & $\begin{array}{c}11 \cdot 87 \pm 0 \cdot 26 \\
(46)\end{array}$ & $\begin{array}{c}8 \cdot 33 \pm 0.44 \\
(39)\end{array}$ & $\begin{array}{c}9 \cdot 15 \pm 0 \cdot 50 \\
(48)\end{array}$ & $\begin{array}{c}7 \cdot 58 \pm 0 \cdot 72 \\
(24)\end{array}$ & $\begin{array}{c}9 \cdot 15 \pm 0 \cdot 88 \\
(13)\end{array}$ \\
\hline 2 & 8 & $\begin{array}{c}12 \cdot 23 \pm 0 \cdot 22 \\
(51)\end{array}$ & $\begin{array}{c}7 \cdot 12 \pm 0 \cdot 44 \\
(34)\end{array}$ & $\begin{array}{c}10 \cdot 60 \pm 0 \cdot 41 \\
(45)\end{array}$ & $\begin{array}{c}8.67 \pm 0.84 \\
(24)\end{array}$ & $\begin{array}{c}9.81 \pm 0.90 \\
(16)\end{array}$ \\
\hline 3 & 7 & - & - & $\begin{array}{c}10 \cdot 38 \pm 0.57 \\
(40)\end{array}$ & $\begin{array}{c}7.42 \pm 0.69 \\
(19)\end{array}$ & $\begin{array}{c}9.06 \pm 0.32 \\
(32)\end{array}$ \\
\hline
\end{tabular}

The number of litters contributing to the above mean values is given in parentheses.

EFFECT OF AGE OF SIRE ON LITTER SIZE

As mentioned above it is not possible to show any effect of age on the male's performance simply by the regression of the litter size with age for the individual males, as this would be confounded with the very significant variation due to period. However, any effect of age should show up in a comparison of the first two groups with Group 3 during Periods 3, 4 and 5, the males in the third group being approximately 9 months younger than those in Groups 1 and 2 . Of course, the males in Groups 1 and 2 died at various times during Periods 4 and 5, so that the experiment at this stage is not balanced, but this should not introduce too much error into the results. Table 2 shows the mean litter sizes sired by the males during the three periods.

It is apparent that there is not a significant difference between the litter sizes sired by the males of the various groups during the last three periods, thus 
indicating that the age of the male in this experiment did not influence litter size.

AGE OF MALE AT BIRTH OF LAST LITTER AND AT DEATH

Table 3 shows the mean age of the males in Groups 1 and 2 at death and at the time of the birth of the last litter sired.

The difference between the two groups is not significant, thus in combination with the other analyses we can say that the removal of one testis has not had a significant influence on size of litters sired or age of cessation of reproductive activity. It is interesting to note that there is a period of reproductive inactivity at the end of the animal's life, although it is much shorter in the male than in the female. Histological examination of the testes of the mice after death indicated that spermatogenesis was still occurring and the testes were not noticeably abnormal. During their last few weeks of life many of the mice,

TABLE 3

AGE OF MALE AT BIRTH OF LAST LITTER AND AT DEATH

\begin{tabular}{l|r|r|r}
\hline & $\begin{array}{c}\text { Group 1 } \\
(9 \text { males })\end{array}$ & $\begin{array}{c}\text { Group 2 } \\
(8 \text { males })\end{array}$ & $\begin{array}{c}\text { Combined } \\
(17 \text { males })\end{array}$ \\
\hline $\begin{array}{c}\text { Age at birth of last } \\
\text { litter (weeks) }\end{array}$ & $\begin{array}{l}84 \cdot 8 \pm 5 \cdot 30 \\
\text { Age at death (weeks) }\end{array}$ & $\begin{array}{r}91 \cdot 1 \pm 4 \cdot 16 \\
101 \cdot 2 \pm 5.81\end{array}$ & $\begin{array}{c}87 \cdot 8 \pm 3 \cdot 42 \\
98 \cdot 7 \pm 4 \cdot 2\end{array}$ \\
\hline
\end{tabular}

especially those which lived longest, looked very weak and moved very slowly, sometimes with a pronounced tremor. It seems likely, therefore, that the cause of the cessation of the breeding in the old mice is physical inability to mate due to somatic ageing.

\section{DISCUSSION}

This experiment demonstrates a significant influence of the sire on the size of litters, an influence which though not very large, might be of biological significance. It therefore cautions against the neglect of the male in work on litter size and embryonic loss. The mean sizes of the litters sired by the seventeen males in Groups 1 and 2 ranged from 7.5 to 11.5. This agrees with the findings of Falconer (1960) in his experiments on the genetics of litter size in mice. Rather surprisingly, ageing of the male or removal of one testis did not have a significant effect on litter size. There is evidence, however, that the fertility of bulls in artificial insemination service does decline with age (Bishop, Campbell, Hancock \& Walton, 1954; Bishop, 1955; Milk Marketing Board, 1950) and this decline is not, of course, caused by physical inability to mate. The available data on the influence of the sire on litter size in pigs, the main polytocous farm animal, is equivocal, some authors claiming an influence for the sire (Gruhn, 1944), others denying it (Musson, 1946).

The influence of the male presumably acts through an effect on fertilization rate or on embryonic loss. Bishop (1964) suggests that the paternal contribution 
to embryonic mortality may be considerable. He postulates that the main cause of this is genetic lethal factors carried by the spermatozoon and that the decline in the fertility of bulls with age is due to the increasing acquisition of lethal factors by the male during his life.

The very significant difference between the sizes of litters produced during the five periods is interesting and worthy of comment. The litter sizes are low during Periods 2 and 4 and high during Periods 1 and 3, with Period 5 intermediate. Although it was not intentionally planned, it happened that during Periods 1 and 3 the length of daylight was for most of the time increasing whereas during Periods 2 and 4 it was mostly decreasing. This may have affected ovulation rate and thus litter size in the same way that varying lengths of daylight are known to affect ovulation in the ferret and sheep (Bisonette, 1936). In an earlier experiment (Finn, 1963), it was not possible to demonstrate a difference in the sizes of litters produced by mice kept under artificial lighting conditions with 8 or $16 \mathrm{hr}$ light per day. However, in that experiment the length of daylight was constant and not changing as in the present experiment, so that the possibility must remain that seasonal variation of daylength influenced litter size in this experiment.

\section{ACKNOWLEDGMENTS}

I would like to thank Mr J. Lewin of the Royal Veterinary College Animal House for his conscientious and enthusiastic care of the mice, Mr R. H. Wimble of Wye College for help with the statistical analysis and Dr M. W. H. Bishop of Bristol University for much helpful advice and criticism.

\section{REFERENCES}

Biggers, J. D., Finn, G. A. \& McLaren, A. (1962) Long-term reproductive performance of female mice. II. Variation of litter size with parity. 7. Reprod. Fertil. 3, 313.

Bishop, M. W. H. (1955) Inter-relationships of semen characteristics. Stud. Fertil. 6, 81.

Bishop, M. W. H. (1964) Paternal contribution to embryonic death. F. Reprod. Fertil. (In press).

Bishop, M. W. H., Camprell, R. C., Hancock, J. L. \& Walton, A. (1954) Semen characteristics and fertility in the bull. F. agric. Sci. 44, 227.

Bissonette, T. H. (1936) Sexual photoperiodicity. Quart. Rev. Biol. 11, 371.

BIrTNER, J. J. (1936) Differences observed in an inbred albino strain of mice following a change in diet. I. Litter size. Nat. Bull. No. 2, Roscoe B. Jackson Memorial Lab. p. 3.

FAzconer, D. S. (1960) The genetics of litter size in mice. F. cell. comp. Physiol. 56, (Suppl. 1), 153.

FinN, C. A. (1963) Reproductive capacity and litter size in mice. Effect of age and environment. 7. Reprod. Fertil. 6, 205.

Gruhn, R. (1944) Untersuchungen über die Fruchtbarkeit beim Deutschem Weisdeschwein. Z. Tier. Zücht Biol. 57, 11.

Kranowska, H. (1960) Studies on heterosis. II. Fertilizaton rate in inbred lines of mice and their crosses. Folia biol. 8, 269.

Mirk Marketing Board (1950) The bull's age and his conception rate. Report No. 1 of the Production Division, p. 31.

Musson, A. L. (1946) The influence of the boar on litter size. F. Anim. Sci. 5, 418. 